\title{
Dissociation between insulin sensitivity of glucose uptake and endothelial function in normal subjects
}

\author{
T. U triainen, S. M äkimattila, A . V irkamäki, R . B ergholm, H .Y ki-J ärvinen \\ D epartment of M edicine, D ivision of E ndocrinology and D iabetology, H elsinki U niversity Central H ospital, H elsinki, Finland
}

Summary Insulin increases limb blood flow in a timeand dose-dependent manner. This effect can be blocked by inhibiting nitric oxide synthesis. These data raise the possibility that insulin resistance is associated with endothelial dysfunction. To examine whether endothelial function and insulin sensitivity are interrelated we quantitated in vivo insulin-stimulated rates of whole body and forearm glucose uptake at a physiological insulin concentration (euglycaemic hyperinsulinaemic clamp, $1 \mathrm{mU} \cdot \mathrm{kg}^{-1} \cdot \mathrm{min}^{-1}$ insulin infusion for $2 \mathrm{~h}$ ) and on another occasion, in vivo endothelial function (blood flow response to intrabrachial infusions of sodium nitroprusside, acetylcholine, and $\mathrm{N}$-monomethyl-L-arginine) in 30 normal male subjects. Subjects were divided into an insulinresistant (IR) and an insulin-sensitive (IS) group based on the median rate of whole body glucose uptake ( $31 \pm 2$ vs $48 \pm 1 \mu \mathrm{mol} \cdot \mathrm{kg}^{-1} \cdot \mathrm{min}^{-1}, \mathrm{p}<0.001$ ). The IR and IS groups were matched for age, but the
IR group had a slightly higher body mass index, percentage of body fat and blood pressure compared to the IS group. The IR group also had diminished insulin-stimulated glucose extraction $(p<0.05)$ compared to the IS group, while basal and insulin-stimulated forearm blood flow rates were identical. There was no difference between the IR and IS groups in the forearm blood flow response to endothelium-dependent (acetylcholine and $\mathrm{N}$-monomethyl-L-arginine) or -independent (sodium nitroprusside) vasoactive drugs. In conclusion, the ability of insulin to stimulate glucose uptake at physiological insulin concentrations and endothelium-dependent vasodilatation are distinct phenomena and do not necessarily coexist. [D iabetologia (1996) 39: 1477-1482]

Keywords Blood flow, nitric oxide, vasodilatation, endothelium.
Insulin increases limb blood flow in a dose- and timedependent manner [1, 2]. This effect of insulin can be blocked by inhibiting nitric oxide synthesis using $\mathrm{N}$ monomethyl-L-arginine (L-N M M A ) [3, 4]. E pidemiological studies have demonstrated an independent association between hyperinsulinaemia and increased

R eceived: 31 M ay 1996 and in revised form: 10 J uly 1996

Corresponding author: H. Y ki-Järvinen M.D., D epartment of Medicine, Division of Endocrinology and Diabetology, U niversity of $\mathrm{Helsinki,} \mathrm{Haartmaninkatu} \mathrm{4,} \mathrm{FIN-00290} \mathrm{Helsinki,}$ Finland

A bbreviations: NID D M, Non-insulin-dependent diabetes mellitus; L-N M MA, N-monomethyl-L-arginine; SNP, sodium nitroprusside; $A C h$, acetylcholine; FFM , fat-free mass; IDDM , insulin-dependent diabetes mellitus. cardiovascular mortality in non-diabetic men $[5,6]$ as well as in patients with non-insulin-dependent diabetes mellitus (NIDDM) [7]. The mechanisms explaining this association are unclear. Given the knowledge that insulin is an endothelium-dependent vasodilator, it is possible that insulin resistance is associated with endothelial dysfunction. Blunted endothelium-dependent vasodilatation has been consistently found in patients with atherosclerotic vascular disease $[8,9]$ and in subjects with increased risk of developing atherosclerosis $[10,11]$. H ypercholesterolaemic individuals however, exhibit normal sensitivity to insulin $[12,13]$. Since hypercholesterolaemia appears to be invariably associated with endothelial dysfunction [14-16], these data raise the possibility that insulin resistance is not necessarily accompanied 
by endothelial dysfunction. Data are conflicting regarding the presence of endothelial dysfunction in patients with essential hypertension [17-19] and NID D M [20, 21], although resistance to the hypoglycaemic effect of insulin uniformly characterizes conditions such as hypertension [22, 23] and NID D M [24].

In none of the studies cited above, have in vivo insulin sensitivity and endothelial function been quantitated in the same subjects. In the present study we measured both parameters to examine whether endothelial function and insulin sensitivity are interrelated. For this purpose, we determined, in 30 normal male subjects, insulin-stimulated rates of glucose uptake at the level of the whole body and across forearm tissues and, on another occasion, the forearm blood flow response to endothelium-dependent (acetycholine, A Ch; L-NMMA) and -independent (sodium nitroprusside, SNP) vasoactive drugs.

\section{Subjects and methods}

\section{Subjects}

Thirty normal male subjects volunteered for the studies. In each subject in vivo insulin sensitivity (euglycaemic insulin clamp combined with measurement of forearm glucose uptake) and, on another occasion, in vivo endothelial function (blood flow response of forearm resistance vessels to $A C h$, SNP and $L^{-}$ NMMA ) were measured with at least a 1-week interval between the studies. The subjects were healthy as judged by history and physical examination, and did not use any drugs known to affect glucose metabolism. E ach subject had a normal fasting plasma glucose and glycosylated hemoglobin $A_{1 C}$ concentration (Table 1). For data analysis, the subjects were ranked according to their rate of whole body glucose uptake, and divided into two subgroups of equal size based on the median rate of whole body glucose uptake $\left(43 \mu \mathrm{mol} \cdot \mathrm{kg}^{-1} \cdot \mathrm{min}^{-1}, 7.7 \mathrm{mg}\right.$ $\left.\mathrm{kg}^{-1} \cdot \min ^{-1}\right)$ : an insulin-resistant (IR ) and an insulin-sensitive (IS) group (Table 1). There was one smoker in the IR and three smokers in the IS group. For 2 days before the insulin sensitivity measurements, the subjects ingested a weight-maintaining diet containing at least $200 \mathrm{~g}$ of carbohydrate per day. W ritten informed consent was obtained after the purpose, nature and potential risks were explained to the subjects. The experimental protocol was approved by the ethical committee of the D epartment of M edicine, $\mathrm{H}$ elsinki U niversity Central $\mathrm{H}$ ospital.

\section{M ethods}

Whole body glucose uptake. The study was begun at 07.30 hours after an overnight fast. Three 18 gauge catheters (Venflon, Viggo-Spectramed, Helsingborg, Sweden) were inserted as previously described [2]. I nsulin and glucose were infused via a catheter inserted in the left antecubital vein. The left hand was kept in a heated box $\left(65^{\circ} \mathrm{C}\right)$ for sampling of arterialized venous blood from a heated dorsal hand vein. The deep branch of the right medial cubital vein draining forearm muscles was cannulated retrogradely so that the tip of the cannula could not be palpated superficially. The euglycaemic hyperinsulinaemic clamp technique was used to assess tissue sensitivity to insulin [25]. Insulin (A ctrapid Human; Novo
Table 1. Physical characteristics of the subjects

\begin{tabular}{|c|c|c|}
\hline & $\begin{array}{l}\text { Insulin- } \\
\text { resistant } \\
\text { subjects } \\
(n=15)\end{array}$ & $\begin{array}{l}\text { Insulin- } \\
\text { sensitive } \\
\text { subjects } \\
(n=15)\end{array}$ \\
\hline A ge (years) & $28 \pm 2$ & $25 \pm 1$ \\
\hline $\mathrm{H}$ eight $(\mathrm{cm})$ & $180 \pm 1$ & $180 \pm 2$ \\
\hline Weight $(\mathrm{kg})$ & $80.1 \pm 3.2$ & $73.2 \pm 1.7$ \\
\hline Body mass index $\left(\mathrm{kg} / \mathrm{m}^{2}\right)$ & $24.7 \pm 0.9$ & $22.5 \pm 0.4^{a}$ \\
\hline Body fat ( $\%)$ & $16.1 \pm 1.5$ & $12.2 \pm 1.0^{\mathrm{a}}$ \\
\hline Fat free mass $(\mathrm{kg})$ & $66.6 \pm 1.7$ & $64.1 \pm 1.1$ \\
\hline Systolic blood pressure (mm H g) & $130 \pm 4$ & $114 \pm 3^{b}$ \\
\hline D iastolic blood pressure (mm Hg) & $75 \pm 3$ & $63 \pm 2^{b}$ \\
\hline M ean arterial blood pressure $(\mathrm{mm} \mathrm{H} \mathrm{g})$ & $94 \pm 3$ & $80 \pm 2^{b}$ \\
\hline Fasting plasma glucose ( $\mathrm{mmol} / \mathrm{l})$ & $5.1 \pm 0.1$ & $5.1 \pm 0.1$ \\
\hline Fasting serum insulin (pmol/l) & $39 \pm 4$ & $27 \pm 4^{a}$ \\
\hline $\mathrm{HbA}_{1 \mathrm{c}}(\%)$ & $4.9 \pm 0.1$ & $5.1 \pm 0.1$ \\
\hline Serum cholesterol (mmol/l) & $4.3 \pm 0.3$ & $4.1 \pm 0.2$ \\
\hline Serum HDL cholesterol ( $\mathrm{mmol} / \mathrm{l})$ & $1.1 \pm 0.1$ & $1.1 \pm 0.1$ \\
\hline Serum LDL cholesterol (mmol/l) & $2.8 \pm 0.2$ & $2.5 \pm 0.2$ \\
\hline Serum triglycerides $(\mathrm{mmol} / \mathrm{l})$ & $1.0 \pm 0.1$ & $0.7 \pm 0.1^{b}$ \\
\hline
\end{tabular}

D ata are mean \pm SE M

${ }^{a} p<0.05,{ }^{b} p<0.01$

N ordisk, Copenhagen, D enmark) was infused in a primed continuous manner at a rate of $1 \mathrm{mU} \cdot \mathrm{kg}^{-1} \cdot \mathrm{min}^{-1}$ for $2 \mathrm{~h}$. N ormoglycaemia was maintained by adjusting the rate of a $20 \%$ glucose infusion based on plasma glucose measurements performed at 5-min intervals. As hepatic glucose production is completely suppressed in normal subjects at the insulin concentrations employed in the present study [26], whole body glucose uptake was calculated from the glucose infusion rate after correcting for changes in the glucose pool size [25]. The reproducibility of whole body glucose uptake measurements with this technique in our laboratory is approximately $7 \%$ [27].

Forearm glucose uptake. Forearm glucose uptake was calculated by multiplying the glucose arteriovenous difference by forearm blood flow [28]. Plasma glucose concentrations were converted to whole blood values by multiplying the plasma glucose concentrations by $1-(0,30 \times$ hematocrit $)$. Forearm blood flow was measured by venousocclusion plethysmography using a mercury in silastic rubber strain-gauge apparatus (H okanson Plethysmograph M odel E C4; B ellevue, Wash., U SA ) [29]. Circulation to the hand was interrupted 2 min before blood sampling and flow measurements, by inflating a paediatric blood pressure cuff around the wrist above systolic blood pressure. Venous return was occluded by inflating a sphygmomanometer cuff around the upper arm to $50 \mathrm{mmH}$ g using a rapid cuff inflator (Hokanson R apid Cuff Inflator Model E 20, Hokanson). The reproducibility of the measurement of the blood flow using this technique is approximately $13 \%$ [2].

E ndothelial function test. The study was performed after a 12-h fast. A 27 gauge needle (Cooper's N eedle Works, B irmingham, UK ) was inserted into the left brachial artery. The needle was kept patent by a $1 \mathrm{ml} / \mathrm{min}$ infusion of $154 \mathrm{mmol} / 1 \mathrm{NaCl}$. A fter $18 \mathrm{~min}$, drugs were infused intrabrachially in the following sequence: SNP (Nipride; Roche, Basel, Switzerland) 3 and $10 \mu \mathrm{g} / \mathrm{min}, 6 \mathrm{~min}$ per dose, $154 \mathrm{mmol} / 1 \mathrm{NaCl} 18 \mathrm{~min}, \mathrm{~A} \mathrm{Ch}$ chloride (M iochol; I olab Corp., Claremont, Calif., U SA ) 7.5 and $15 \mu \mathrm{g} / \mathrm{min}, 6 \mathrm{~min}$ per dose, $154 \mathrm{mmol} / 1 \mathrm{NaCl} 18 \mathrm{~min}, \mathrm{~L}^{-}$ NM M A (Clinalfa A g, Läufelfingen, Switzerland) $4 \mu \mathrm{mol} / \mathrm{min}$ for $6 \mathrm{~min}$. The intra-arterial infusion rate was held constant ( $1 \mathrm{ml} / \mathrm{min}$ ) throughout the study. Forearm blood flow was measured at 15-s intervals during the last 3 min of each drug and 
saline infusion period. Blood flow was recorded in both the infused (experimental) and non-infused (control) forearms simultaneously using strain-gauge plethysmography as described above. A $n$ analogue-to-digital converter ( $M$ acL ab/4e; A D Instruments Pty L td, Castle H ill, A ustralia) connected to a personal computer was used for recording and analysis of the blood flow data during endothelial function tests.

O ther measurements. Blood pressure was measured using a mercury sphygmomanometer. Fat free mass (FFM) and the percentage of body fat were determined using bioelectrical impedance analysis ( $B$ ioE lectrical Impedance A nalyzer System model \#BIA -101A; RJ L Systems, D etroit, M ich., U SA ) [30]. The plasma glucose concentration was measured in duplicate with the glucose oxidase method [31] using a Beckman G lucose A nalyzer II (Beckman Instruments, Fullerton, Calif., U SA ). Serum free insulin was determined by double antibody radioimmunoassay (Pharmacia Insulin RIA kit; Pharmacia, U ppsala, Sweden) after precipitation with polyethylene glycol [32]. The serum concentrations of cholesterol, triglycerides and high-density lipoprotein (HDL) cholesterol were determined by enzymatic colourimetric assays with an automated Cobas M ira analyzer (H offman-L a R oche, B asel, Switzerland) [33]. L ow-density lipoprotein (LD L) cholesterol concentration was calculated by the formula of Friedewald.

Statistical analysis. Student's unpaired t-test was used to compare mean values of the IR and IS groups. Comparison of blood flow responses to vasoactive drugs during the endothelial function test were performed by repeated measures analysis of variance followed by pairwise comparison using the $B$ onferroni test. A II calculations were made using the SY STA T statistical package (SY STA T Inc., E vanston, III., U SA ). D ata are expressed as mean \pm SE M . P -values less than 0.05 were considered to be statistically significant.

\section{Results}

Characteristics of the insulin-resistant (IR ) and insulinsensitive (IS) groups (Table 1). The IR and IS groups were matched for age, but the IR group had slightly higher body mass index (BMI), percentage of body fat, arterial blood pressure and serum triglyceride concentration. Serum total and LD L-cholesterol concentrations were comparable between groups.

Insulin sensitivity. D uring the insulin infusion, normoglycaemia was maintained in both the IR (5.2 \pm $0.1 \mathrm{mmol} / \mathrm{l})$ and IS groups $(5.2 \pm 0.1 \mathrm{mmol} / \mathrm{l})$. Serum free insulin concentrations averaged $381 \pm 12 \mathrm{pmol} / \mathrm{l}$ and $365 \pm 14 \mathrm{pmol} / \mathrm{l}$ (NS), respectively. Whole body glucose uptake, expressed per kg body weight (BW) was, by definition, $36 \%$ lower in the IR ( $31 \pm 2 \mu \mathrm{mol}$. $\left.\mathrm{kg} \mathrm{BW}^{-1} \cdot \mathrm{min}^{-1}\right)$ than the IS ( $48 \pm 1 \mu \mathrm{mol} \cdot \mathrm{kg} \mathrm{BW}^{-1}$ $\mathrm{min}^{-1}, \mathrm{p}<0.001$ ) group. The rate of glucose uptake, expressed per kg FFM, was also significantly lower in the IR $\left(37 \pm 3 \mu \mathrm{mol} \cdot \mathrm{kg} \mathrm{FFM}^{-1} \cdot \mathrm{min}^{-1}\right)$ than the IS (55 \pm $1 \mu \mathrm{mol} \cdot \mathrm{kg} \mathrm{FFM}^{-1} \cdot \mathrm{min}^{-1}, \mathrm{p}<0.001$ ) group (Fig. 1).

Forearm glucose uptake was significantly lower in the IR $\left(3.9 \pm 0.4 \mu \mathrm{mol} \cdot \mathrm{dl}\right.$ forearm $\left.{ }^{-1} \cdot \mathrm{min}^{-1}\right)$ than the IS $\left(5.0 \pm 0.4 \mu \mathrm{mol} \cdot \mathrm{dl}\right.$ forearm $\left.{ }^{-1} \cdot \mathrm{min}^{-1}, \quad \mathrm{p}<0.05\right)$ group. The defect in forearm glucose uptake was
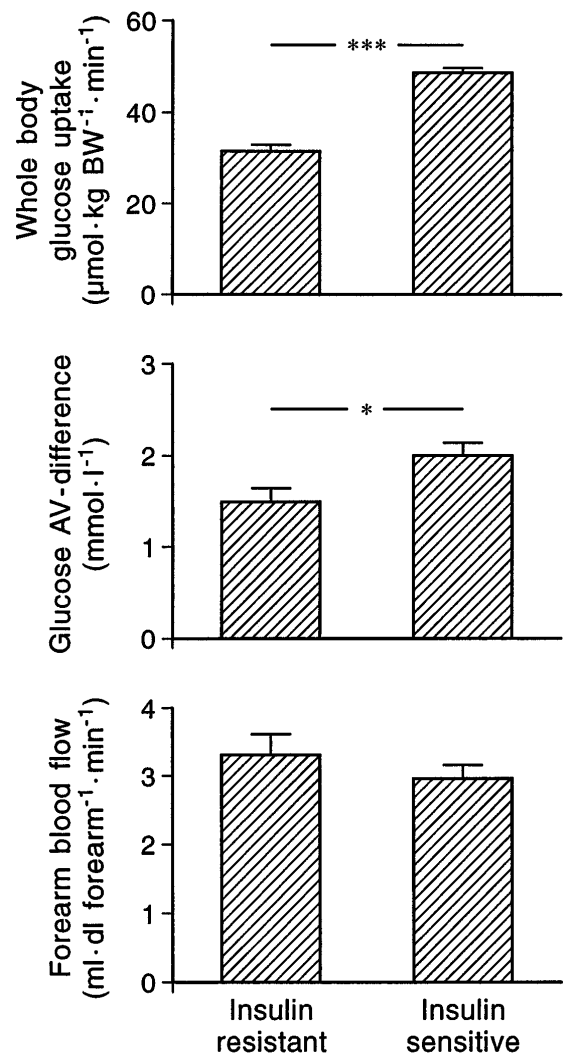

Fig. 1. Whole body glucose uptake (upper panel) calculated per kg body weight (BW), glucose arteriovenous difference (middle panel) and insulin-stimulated blood flow (lower panel) across the forearm in insulin-resistant and insulin-sensitive subjects. $* p<0.05 ; * * * p<0.001$

localized to glucose extraction, since the glucose arterio-venous difference was significantly lower in the IR $(1.5 \pm 0.1 \mathrm{mmol} / \mathrm{l})$ than the $1 \mathrm{~S}(2.0 \pm 0.1 \mathrm{mmol} / \mathrm{l}$, $p<0.05$ ) group (Fig. 1). Insulin-stimulated forearm blood flow was similar in both groups $(3.3 \pm 0.3$ vs $2.9 \pm 0.2 \mathrm{ml} \cdot \mathrm{dl}$ forearm ${ }^{-1} \cdot \mathrm{min}^{-1}$, IR vS IS, NS) (Fig.1). The increases in blood flow above basal $\left(0.4 \pm 0.2\right.$ vs $0.4 \pm 0.2 \mathrm{ml} \cdot \mathrm{dl}$ forearm ${ }^{-1} \cdot \mathrm{min}^{-1}$, respectively) were also comparable between the groups. The increase in blood flow was statistically significant in both the IR $(p<0.05)$ and IS groups $(p<0.05)$.

E ndothelial function. The blood flow responses in the experimental forearm to SNP, A Ch and L-NMMA are shown in Figure 2. There were no differences in the blood flow responses to any of the drugs between the IR and IS groups. This remained true even if the ratio of blood flow between the experimental and control forearm, or forearm vascular resistance were used in data analysis (data not shown). N either were the percentage increases in forearm blood flow in response to two doses of SNP $(279 \pm 31 \%$, $464 \pm 45 \%$ vs $285 \pm 23 \%, 524 \pm 49 \%$, SNP $3,10 \mu \mathrm{g} /$ min in IR vs IS, NS) or A Ch $(200 \pm 32 \%, 280 \pm 40 \%$ vs $230 \pm 32 \%, 323 \pm 49 \%$, A Ch $7.5,15 \mu \mathrm{g} / \mathrm{min}$ in IR 

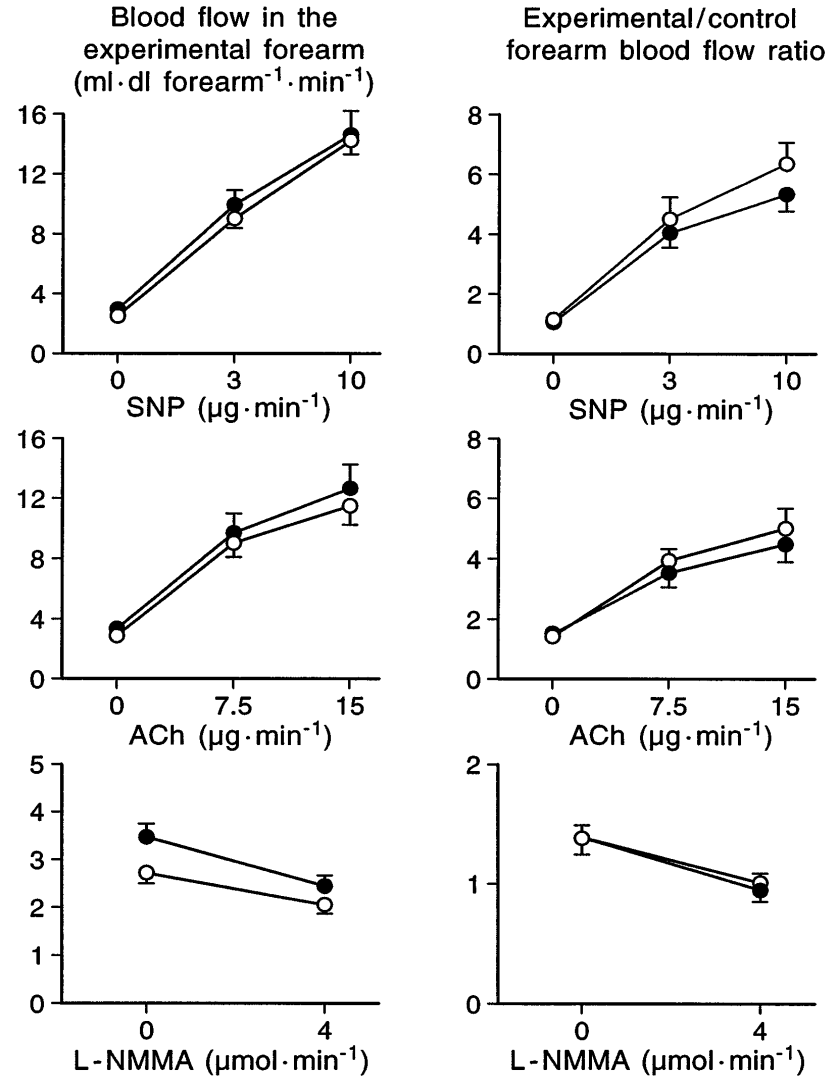

Fig. 2. The response of the experimental forearm blood flow (left panels) and the experimental/control forearm blood flow ratio (right panels) to increasing doses of SNP (upper panels), A Ch (middle panels) and L-N M M A (lower panels) in the insulin-resistant (- - ) and insulin sensitive (-○-) groups

vs IS, NS) or the percentage decrease in blood flow by L-N M M A ( $28 \pm 3 \%$ vs $24 \pm 2 \%$, NS) (Fig. 3) statistically different between the groups. R esponses to A Ch and to SN P are known to be affected by forearm length [34]. However, forearm lengths (measured from medial epicondyle to ulnar styloid) were similar in both groups ( $28.2 \pm 0.4$ vs $27.8 \pm 0.4 \mathrm{~cm}, \mathrm{NS})$.

In the entire study group, mean arterial blood pressure $(r=-0.53, p<0.01)$, BMI $(r=-0.43$, $p<0.02)$ and percentage body fat $(r=-0.43$, $p<0.02$ ) were negatively correlated with whole body glucose uptake. In contrast, these parameters were not correlated with the blood flow response to either dose of A Ch or SN P, or with the percentage decrease in flow induced by L-N M M A (Fig. 3).

\section{Discussion}

In the present study, insulin sensitivity of glucose uptake and the blood flow response of forearm resistance vessels to endothelium-dependent and -independent vasoactive agents were measured in a group of normal male subjects. The subjects were divided into two subgroups of equal size based on their

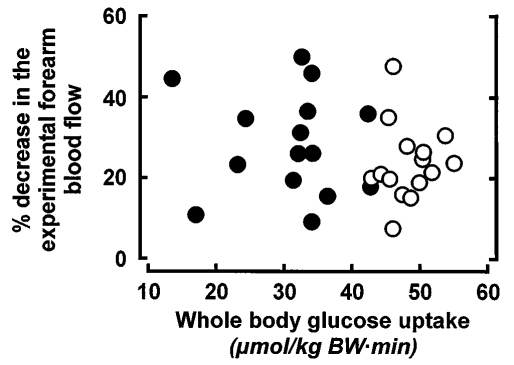

Fig. 3. A scatter plot showing the lack of association between whole body glucose uptake and the percent decrease in forearm blood flow in response to intrabrachial infusion of L-NMMA in insulin-resistant (0) and insulin-sensitive (O) subjects

insulin-stimulated rate of whole body glucose uptake. The insulin-resistant subgroup had, by definition, significantly lower whole body glucose uptake than the sensitive subgroup. This resistance could be attributed to a defect in glucose extraction across forearm tissues. Forearm blood flow was, however, similar both during infusion of insulin, and during infusion of endothelium-dependent ( $\mathrm{A}$ Ch, L-N M M A ) and -independent (SNP) vasoactive agents. These data suggest that endothelial function and insulin stimulation of glucose uptake at physiological insulin concentrations are differently regulated phenomena.

We classified the subjects as "insulin-resistant" and "insulin-sensitive" based on the measured rate of whole body glucose uptake. The subjects classified as insulin-resistant had a mean rate of whole body glucose uptake of $31 \mu \mathrm{mol} \cdot \mathrm{kg}^{-1} \cdot \mathrm{min}^{-1}\left(5.6 \mathrm{mg} \cdot \mathrm{kg}^{-1}\right.$. $\left.\mathrm{min}^{-1}\right)$. This rate is clearly higher than the rates which characterize typical NIDD M patients [24], but lower than the rates characterizing average Finnish healthy subjects of the same age and BMI [35]. It may be noted that no prospective data regarding the effect of insulin sensitivity measured with the clamp technique as a predictor of NIDDM or cardiovascular mortality are available in Caucasians. It is therefore unclear, whether the degree of insulin resistance characterizing the "insulin-resistant" subjects in the present study is associated with a significant risk for the subject's subsequent health.

The ability of insulin to stimulate muscle blood flow depends both on the duration and dose of insulin $[1,2,36,37]$. A t physiological insulin concentrations, such as those employed in the present study, insulin increases glucose extraction maximally within 30-60 min [2]. In contrast, the effects on limb blood flow are controversial, some studies showing no or marginal increases [2,36, 38-40], while others have found significant increases $(20-60 \%)$ [3, 41, 42] during this time period. During prolonged [ 1 , $37]$, or high-dose $[1,2,43]$ insulin infusions, blood flow increases markedly up to $80-110 \%$ above basal. Under these conditions, glucose extraction remains constant [1, 2]. Consequently, one would expect 
defects in glucose extraction to predominate when insulin-resistant and sensitive individuals are compared using physiological insulin concentrations, and defects in blood flow to distinguish between the groups in studies using supraphysiological insulin concentrations. In keeping with this postulate, defects in glucose extraction have explained insulin resistance in patients with essential hypertension [44], insulin-dependent diabetes (IDDM) [45] and NIDDM $[24,46]$ at physiological insulin concentrations. At high insulin concentrations, defects in blood flow have been found in subjects with marginally elevated blood pressure [43], and in patients with IDDM [47] and NIDDM [48], although these findings have not been uniform in either hypertensive subjects $[49,50]$ or in patients with NIDDM $[51,52]$. In keeping with these data, the defect in glucose uptake between our insulin-resistant and sensitive individuals, in whom insulin sensitivity was measured using a physiological insulin concentration, was localized to glucose extraction.

The mechanism by which insulin and $\mathrm{A} C \mathrm{C}$ induce endothelium-dependent vasodilatation differs in several respects. In vivo insulin-induced vasodilatation can be blocked by L-N M M A , an inhibitor of endothelial cell nitric oxide synthase $[3,4]$ and by blocking corticotropin-releasing hormone-release by dexamethasone [53]. H owever, the precise mechanism coupling nitric oxide to insulin-induced vasodilatation is presently unclear. Compared to $\mathrm{A} C \mathrm{C}$, the vasodilatory effect of insulin is slow. While $\mathrm{A} C \mathrm{C}$ increases blood flow several-fold within minutes in normal subjects [54], doubling of blood flow with high insulin concentrations takes hours [2]. In support of differences in the mechanism of insulin vs A Ch induced vasodilatation, Taddei et al. [55] observed blunted endothelium-dependent responses in hypertensive as compared to normotensive subjects, but normal potentiation of $\mathrm{A} C h$-induced vasodilatation by insulin. A fter submission of the present manuscript, Petrie et al. [56] reported that basal endothelial nitric oxide synthesis, measured as the percent decrease in the forearm blood flow ratio during infusion of L-NMMA, was inversely correlated with whole body insulin sensitivity in 15 normotensive males (age 27 years, B M I $24.6 \mathrm{~kg} / \mathrm{m}^{2}$, blood pressure $130 / 69 \mathrm{mmH} \mathrm{g}$ ). We could not, however, confirm this result in the group of 30 normotensive males (age 27 years, BMI $23.6 \mathrm{~kg} / \mathrm{m}^{2}$, blood pressure $122 / 69 \mathrm{mmH} \mathrm{g}$ ) in the present study. We therefore conclude that endothelial function and insulin sensitivity of glucose uptake under physiological conditions do not necessarily change in parallel and are therefore likely to be differently regulated phenomena.

A cknowledgements. We thank M s. S. H ämäläinen, R . T., for excellent technical assistance during the studies. The A cademy of Finland (H.Y.), the A hokas (H.Y.) and Sigrid J uselius (H.Y.)
Foundations, and the M.D./Ph.D. program of the U niversity of Helsinki (T.U.) are gratefully acknowledged for financial support.

\section{References}

1. Laakso M, E delman SV, B rechtel G, Baron A D (1990) D ecreased effect of insulin to stimulate skeletal muscle blood flow in obese man. A novel mechanism for insulin resistance. J Clin Invest 85: 1844-1852

2. U triainen $T, M$ almström $R, M$ äkimattila $S, Y$ ki-Järvinen $H$ (1995) M ethodological aspects, dose-response characteristics and causes of interindividual variation in insulin stimulation of limb blood flow in normal subjects. Diabetologia 38: 555564

3. Steinberg H O, B rechtel G, J ohnson A, Fineberg N, B aron A D (1994) Insulin-mediated skeletal muscle vasodilation is nitric oxide dependent. A novel action of insulin to increase nitric oxide release. J Clin I nvest 94: 1172-1179

4. Scherrer U, R andin D, Vollenweider P, Vollenweider L, N icod $P$ (1994) Nitric oxide release accounts for insulin's vascular effects in humans. J Clin Invest 94: 2511-2515

5. Pyörälä K (1979) R elationship of glucose tolerance and plasma insulin to the incidence of coronary heart disease: results from two population studies in Finland. Diabetes Care 2: $131-141$

6. Fontbonne A, Charles M A, Thibult N, et al. (1991) H yperinsulinemia as a predictor of coronary heart disease mortality in a healthy population: the Paris Prospective Study, 15-year follow-up. D iabetologia 34: 356-361

7. R önnemaa T, L aakso M , Pyörälä K, K allio V, Puukka P (1991) $\mathrm{H}$ igh fasting plasma insulin is an indicator of coronary heart disease in non-insulin-dependent diabetic patients and nondiabetic subjects. A rterioscler Thromb 11: 80-90

8. Chester A H, O'Neil GS, M oncada S, Tadjkarimi S, Y acoub M H (1990) L ow basal and stimulated release of nitric oxide in atherosclerotic epicardial coronary arteries. Lancet 336: 897-900

9. E gashira K, Inou T, H irooka $Y$, et al. (1993) Impaired coronary blood flow response to acetylcholine in patients with coronary risk factors and proximal atherosclerotic lesions. J Clin Invest 91: 29-37

10. Vita JA, Treasure CB, Nabel E G, et al. (1990) Coronary vasomotor response to acetylcholine relates to risk factors for coronary artery disease. Circulation 81: 491-497

11. Q uyyumi A A, D akak N, A ndrews N P, et al. (1995) Nitric oxide activity in the human coronary circulation. I mpact of risk factors for coronary atherosclerosis. J Clin Invest 95: 17471755

12. K arhapää P, Voutilainen E, Kovanen PT, L aakso M (1993) Insulin resistance in familial and nonfamilial hypercholesterolemia. A rterioscler Thromb 13: 41-47

13. Sheu W H -H, Shieh S-M , Fuh M M -T, et al. (1993) I nsulin resistance, glucose intolerance, and hyperinsulinemia. Hypertriglyceridemia versus hypercholesterolemia. A rterioscler Thromb 13: 367-370

14. Chowienczyk PJ, Watts G F, Cockcroft J, R itter J M (1992) Impaired endothelium-dependent vasodilation of forearm resistance vessels in hypercholesterolaemia. $L$ ancet 340: 1430-1432

15. Craeger M A, Cooke J P, M endelsohn ME, et al. (1990) I mpaired vasodilation of forearm resistance vessels in hypercholesterolemic humans. J Clin Invest 86: 228-234

16. Leung W-H, Lau C-P, Wong C-K (1993) B eneficial effect of cholesterol-lowering therapy on coronary endothelium-dependent relaxation in hypercholesterolaemic patients. $L$ ancet 341: 1496- 1500

17. Panza J A , Q uyyumi A A , Brush J E, E pstein SE (1990) A bnormal endothelium-dependent vascular relaxation in patients with essential hypertension. N E ngl J Med 323: 22-27 
18. E gashira K, Suzuki S, H irooka Y, et al. (1995) Impaired endothelium-dependent vasodilation of large arteries and resistance coronary arteries in patients with essential hypertension. $D$ ifferent responses to acetylcholine and substance $\mathrm{P}$. H ypertension 25: 201-206

19. Cockcroft J R, Chowienczyk PJ, Benjamin N, R itter J M (1994) Preserved endothelium-dependent vasodilation in patients with essential hypertension. N E ngl J M ed 330: 1036-1040

20. M cVeigh GE, Brennan G M , Johnston GD, et al. (1992) Impaired endothelium-dependent and independent vasodilation in patients with type 2 (non-insulin-dependent) diabetes mellitus. D iabetologia 35: 771-776

21. Ting H H, Timimi FK, B oles K S, Craeger SJ, G anz P, Craeger M A (1996) Vitamin C improves endothelium-dependent vasodilation in patients with non-insulin-dependent diabetes mellitus. J Clin Invest 97: 22-28

22. Ferrannini E, Buzzigoli G, B onadonna R, et al. (1987) Insulin resistance in essential hypertension. $\mathrm{N}$ Engl J M ed 317: 350357

23. Pollare $T$, Lithell $H, B$ erne $C$ (1990) Insulin resistance is a characteristic feature of primary hypertension independent of obesity. M etabolism 39: 167-174

24. D eFronzo R A, G unnarsson R, B jörkman O, O Isson M, Wahren J (1985) Effects of insulin on peripheral and splanchnic glucose metabolism in noninsulin-dependent (type II) diabetes mellitus. J Clin Invest 76: 149-155

25. Defronzo RA, Tobin JD, A ndres R (1979) Glucose clamp technique: a method for quantifying insulin secretion and resistance. A m J Physiol 237:E 214-E 223

26. $\mathrm{H}$ other-N ielsen $O$, M engel $A$, M øller J, R asmussen $O$, Schmitz O, Beck-Nielsen H (1992) A ssessment of glucose turnover rates in euglycaemic clamp studies using primed-constant [3${ }^{3} \mathrm{H}$ ]-glucose infusion and labelled or unlabelled glucose infusates. D iabet M ed 9: 840-849

27. Y ki-Järvinen $\mathrm{H}$ (1984) Insulin sensitivity during the menstrual cycle. J Clin Endocrinol M etab 59: 350-353

28. Z ierler KL (1961) Theory of the use of arteriovenous concentration differences for measuring metabolism in steady state and non-steady states. J Clin Invest 40: 2111-2125

29. Clarke R SJ, Hellon R F (1957) Venous collection in forearm and hand measured by the strain-gauge and volume plethysmograph. Clin Sci 16: 103-117

30. Lukaski H C, J ohnson PE, B olonchuk W W, Lykken GI (1985) A ssessment of fat-free mass using bioelectrical impedance measurements of the human body. A m J Clin N utr 41: 810-817

31. Kadish A H, Little R L, Sternberg J C (1968) A new and rapid method for the determination of glucose by measurement of rate of oxygen consumption. Clin Chem 14: 116-131

32. D esbuquois B, A urbach GD (1971) U se of polyethylene glycol to separate free and antibody-bound peptide hormones in radioimmunoassays. J Clin E ndocrinol 33: 732-738

33. Syvänne $M$, V uorinen- $M$ arkkola $H$, H ilden $H$, Taskinen $M-R$ (1993) G emfibrozil reduces postprandial lipemia in non-insulin-dependent diabetes mellitus. A rterioscler Thromb 13: 286-295

34. Chowienczyk PJ, Cockcroft JR, Ritter J M (1994) Blood flow responses to intra-arterial acetylcholine in man: effects of basal flow and conduit vessel length. Clin Sci 87: 45-51

35. Y ki-J ärvinen $\mathrm{H}$ (1995) R ole of insulin resistance in the pathogenesis of NIDD M . D iabetologia 38: 1378-1388

36. Bonadonna R C, Saccomani M P, Seely L, et al. (1993) G lucose transport in human skeletal muscle. The in vivo response to insulin. D iabetes 42: 191-198

37. L undgren F, E dén $E$, A rfvidsson B , L undholm K (1991) Insulin time-dependent effects on the leg exchange of glucose and amino acids in man. E ur J Clin Invest 21: 421-429

38. Y ki-Järvinen H, Y oung A A, Lamkin C, Foley J E (1987) Kinetics of glucose disposal in whole body and across the forearm in man. J Clin Invest 79: 1713-1719
39. L embo G, Napoli R, Capaldo B, et al. (1992) A bnormal sympathetic overactivity evoked by insulin in the skeletal muscle of patients with essential hypertension. J Clin Invest 90: 24-29

40. N uutila P, R aitakari M, Laine $H$, et al. (1996) R ole of blood flow in regulating insulin-stimulated glucose uptake in humans. Studies using bradykinin, $\left[{ }^{15} \mathrm{O}\right]$ water and $\left[{ }^{18} \mathrm{~F}\right]$ fluorodeoxy-glucose and positron emission tomography. J Clin Invest 97: 1741-1747

41. A nderson E A , H offman R P, B alon TW, Sinkey CA, M ark A L (1991) Hyperinsulinemia produces both sympathetic neural activation and vasodilation in normal humans. J Clin Invest 87: 2246-2252

42. Vollenweider P, Tappy L, R andin D, et al. (1993) D ifferential effects of hyperinsulinemia and carbohydrate metabolism on sympathetic nerve activity and muscle blood flow in humans. J Clin Invest 92: 147-154

43. B aron A D, B rechtel-H ook G, Johnson A, Hardin D (1993) Skeletal muscle blood flow. A possible link between insulin resistance and blood pressure. H ypertension 21: 129-135

44. Natali A, Santoro D, Palombo C, Cerri M, G hione S, Ferrannini $E$ (1991) Impaired insulin action on skeletal muscle metabolism in essential hypertension. Hypertension 17: 170 178

45. Y ki-Järvinen H, Sahlin K, R en J M , K oivisto VA (1990) L ocalization of rate-limiting defect for glucose disposal in skeletal muscle of insulin-resistant type 1 diabetic patients. Diabetes 39: 157-167

46. Bonadonna RC, Del Prato S, Saccomani MP, et al. (1993) Transmembrane glucose transport in skeletal muscle of patients with non-insulin-dependent diabetes. J Clin Invest 92: 486-494

47. B aron A D, L aakso M, B rechtel G, E delman SV (1991) M echanism of insulin resistance in insulin-dependent diabetes mellitus: a major role for reduced skeletal muscle blood flow. J Clin Endocrinol M etab 73: 637-643

48. L aakso M, E delman SV, B rechtel G, Baron A D (1992) Impaired insulin-mediated skeletal muscle blood flow in patients with N ID D M. D iabetes 41: 1076-1083

49. H ulthén U L, Endre T, M attiasson I, B erglund G (1995) Insulin and forearm vasodilation in hypertension-prone men. $\mathrm{H}$ ypertension 25: 214-218

50. O'Shaughnessy I M, M yers TJ, Stepniakowski K, et al. (1995) G lucose metabolism in abdominally obese hypertensive and normotensive subjects. $\mathrm{H}$ ypertension 26: 186-192

51. Dela F, Larsen JJ, M ikines KJ, G albo H (1995) Normal effect of insulin to stimulate leg blood flow in NIDDM. Diabetes 44: 221-226

52. Tack CJJ, Smits P, Willemsen JJ, L enders JW M, Thien T, L utterman JA (1996) E ffects of insulin on vascular tone and sympathetic nervous system in NID D M . D iabetes 45: 15-22

53. Scherrer $U$, Vollenweider $P, R$ andin $D$, Jéquier $E, N$ icod $P$, Tappy L (1993) Suppression of insulin-induced sympathetic activation and vasodilation by dexamethasone in humans. Circulation 88: 388-394

54. Chowienczyk PJ, C ockcroft J R, R itter J M (1995) Inhibition of acetylcholinesterase selectively potentiates $\mathrm{N}^{\mathrm{G}}$-monomethyl$\mathrm{L}$-arginine-resistant actions of acetylcholine in human forearm vasculature. Clin Sci 88: 111-117

55. Taddei S, Virdis A , M attei P, N atali A , Ferrannini E , Salvetti A (1995) E ffect of insulin on acetylcholine-induced vasodilation in normotensive subjects and patients with essential hypertension. Circulation 92: 2911-2918

56. Petrie J R, U eda S, Webb D J, Elliott H L, Connell J M C (1996) E ndothelial nitric oxide production and insulin sensitivity. A physiological link with implications for pathogenesis of cardiovascular disease. Circulation 93: 1331-1333 